\title{
Responsibility attribution in gender-based domestic violence: A study bridging corpus-assisted discourse analysis and readers' perception
}

\author{
Chiara Meluzzi ${ }^{\text {a, }}{ }^{*}$, Erica Pinelli ${ }^{\text {c }}$, Elena Valvason ${ }^{\text {b }}$, Chiara Zanchi ${ }^{\text {b }}$ \\ a Department of Literary Studies, Philology and Linguistics, Section of Linguistics, University of Milan, Italy \\ ${ }^{\mathrm{b}}$ Department of Humanities, Section of Linguistics, University of Pavia, Italy \\ ${ }^{c}$ Department of Humanities, Section of Foreign Languages and Literatures, University of Pavia, Italy
}

\section{A R T I C L E I N F O}

Article history:

\section{Keywords:}

Media discourse

Gender-based violence

Cognitive grammar

Corpus-assisted discourse studies

Perception studies

\begin{abstract}
A B S T R A C T
This paper investigates how argument structure constructions (see e.g. Goldberg 1995) are used by Italian newspapers to portray gender-based violence (GBV), how their usage affects responsibility attribution to perpetrators, and how such usage is perceived by Italian readers. The assumption is that constructions critically affect meaning: constructional choices prompt different viewpoints of the same event. For the corpus study, we collected 40 articles from local newspapers and annotated 720 constructions denoting GBV events. Constructions suppressing/backgrounding the perpetrator or depicting the event as a bare happening were the most frequent. Building upon these results, for the perception study, 274 participants read an author-constructed news report portraying GBV and answered four speculative questions about the identity of the perpetrator and the victim. Respondents were divided into groups and each group was presented with a stimulus article containing different constructions of the GBV event surrounded by the same information frame. In line with previous studies, it was found that the perpetrator could be assigned less responsibility when the passive and nominal constructions were employed.
\end{abstract}

() 2021 Published by Elsevier B.V.

\section{Introduction ${ }^{1}$}

This paper investigates how argument structure constructions (see e.g. Goldberg, 1995) are used by Italian newspapers to portray gender-based violence (GBV), how their usage affects responsibility attribution to perpetrators, and how such usage is perceived by Italian readers.

\footnotetext{
* Corresponding author. Department of Literary Studies, Philology and Linguistics, Section of Linguistics, University of Milan, Via Festa del Perdono, 7 , 10100, Milano, MI, Italy.

E-mail addresses: chiara.meluzzi@unimi.it (C. Meluzzi), erica.pinelli@unipv.it (E. Pinelli), elena.valvason01@universitadipavia.it (E. Valvason), chiara.zanchi01@unipv.it (C. Zanchi).

${ }^{1}$ This research was carried out within the crowdfunded project Words Matter (https://sites.google.com/unipv.it/wordsmatter/). All authors are equally responsible for the content of the paper. However, for academic purposes, Chiara Meluzzi is responsible for 4, 4.2, 4.3, 5.2, 6 and 7; Elena Valvason for 4.1 and 5.1; Erica Pinelli for 3.2 and 3.3; and Chiara Zanchi for 1, 2 and 3.1.
} 
A 2018 ANSA report reveals that " $56.8 \%$ of boys and $38.8 \%$ of girls believe that she is at least partly co-responsible for the violence" that she underwent (our translation and emphasis). ${ }^{2}$ In spite of this, a 2019 ISTAT report suggests that GBV in 2018 crossed fewer demographic and social boundaries than before: the percentage of agreement with at least one among the GBV stereotypes under consideration decreases with decreasing age, increasing levels of education, and female gender. ${ }^{3}$ The persistence of gender-based stereotypes, however, is mirrored in the power asymmetries described in the Gender Gap report, which examines the gap between women and men in four key social areas: health, education, economics, and politics. ${ }^{4}$

If women represent a weaker social group with respect to men, they are also likely to undergo misrepresentation in media discourse, as it happens with other weak social groups in asymmetric power relationships experiencing personalized violence (Coates and Wade, 2007; on previous studies concerning the representation of GBV in the Italian context, see references below in this section). The pervasive repetition of biased "storytelling patterns" results in the creation or strengthening of expectations regarding how a certain event happens in the public sphere (e.g. Fagoaga, 1994). Since Lakoff's (1973, 1975) seminal work on gendered language, it has been argued that language creates and mirrors sexual inequality (Graddoll and Swann, 1989; Goddard and Saunders, 2000), resulting in what Mills (2008: 22) calls "indirect sexism": a set of indirect linguistic strategies, which construct discourses entailing an unbalanced power relationship between men and women. ${ }^{5}$

Such misrepresentation may well result from a combination of factors other than the persistence of gender-based stereotypes, including institutionalized professional imperatives and commercial interests (cf. the distinction among misinformation, dis-information and mal-information, in e.g. Carmi et al., 2020). All these factors may contribute to driving media toward the use of well-worn, routinized, and frequently unjust formulas to report GBV events. Whether intentionally malicious or not, media discourse crucially has the power of shaping our ways to interpret events by placing them in a certain frame, that is, "any system of concepts related in such a way that to understand any one of them you have to understand the whole structure in which it fits" (Fillmore, 1982: 111; see also Lakoff, 2004, 2009).

Previous studies of how GBV is depicted in media discourse mostly employ the methodology of Critical Discourse Analysis and sometimes employ corpus-assisted methods to analyze lexical items and collocations as prompts for evoking frames (for a review of CDA and corpus approaches to discourse see (Valvason, 2021)): see, among others, Ehrlich (2003), O'Hara (2012) and Tranchese and Zollo (2013) on English; Fagoaga (1994) and Santaemilia and Maruenda (2014) on Spanish; Abis and Orrù (2016), (Formato, 2017, 2019), Busso et al. (2021) and Belluati (2021) with references on Italian. As Christopher Hart has pointed out in several works (2018a, 2018b, 2018c, 2021; Hart and Fuoli, 2020) the latest CDA practice emphasizes the need to use multiple means of inquiry to avoid a subjective selection and reading of textual data: he recommends triangulation. The CDA research ventures with triangulation have gone in different directions, including corpus (O'Halloran, 2007; Gabrielatos and Baker, 2008) and Cognitive Linguistics. In the case of the latter partnership, CDA has mostly embraced the theory of conceptual metaphor (Lakoff and Johnson, 1980) in the guise of what is known as Critical Metaphor Analysis (e.g. Chilton, 1996; Santa Ana, 2002; Charteris-Black, 2004). CDA only rarely ventured to other theoretical tools of Cognitive Linguistics (for exceptions, cf. Hart, 2010, 2011, 2013, 2015).

In parallel, it is still relatively rare to find investigations in which CDA is complemented with experimental methodologies (but see Subtirelu and Gopavaram, 2016; Fuoli and Hart, 2018; Hart, 2018a, 2018b, 2018c, 2021; Hart and Fuoli, 2020). Yet, concerning the constructions investigated in this paper, Henley et al. (1995) provide a corpus and a psycholinguistic study of the usage and perception of passive constructions in U.S. media reports of GBV. More recently, Bohner (2001) has carried out a perception study on German native speakers focusing on the effects of the passive voice in sexual assault reports. Hart (2018a, 2018b, 2018c) combines CDA and perception studies to investigate how the selection of transitive vs. reciprocal constructions can produce differences in how news reports of political protests are interpreted in terms of blame apportionment and perception of social actors' level of aggression (for definitions of transitive, reciprocal and other types of constructions, see Section 2).

Along with Hart (2021), this is one of the first studies carried out in an Italian context that apply a cognitive approach of constructions to a specific case study, in order to investigate the perceptual consequences of constructional choices in discourse. This paper also combines a corpus-assisted approach to discourse analysis and experimental studies. From this perspective, we first investigated the constructional usages in a corpus of GBV reports to understand if and how grammatical constructions have the potential to relieve perpetrators of their responsibility in GBV events. Second, we carried out two

\footnotetext{
2 The ANSA (Agenzia Nazionale Stampa Associata) is the leading wire service in Italy. The cited report can be read here: http://www.ansa.it/canale saluteebenessere/notizie/stili_di_vita/2018/11/30/violenza-donne-per-4-giovani-su-10-dipende-anche-da-lei_b834f656-fdf2-4a0c-8de5-2d6c6dfcfc82. html. In Italy, as well as in the other European Union member states, the legal category of femicide/feminicide does not exist (sometimes, the terms femicide and feminicide are distinguished in the literature, cf. e.g. Karadole, 2012; other authors opt for other expressions, see e.g. 'intimate partner violence/ femicide' in Monckton-Smith, 2012, 'intimate murder' in Wykes, 1995, and 'patriarchal terrorism' in Johnson, 1995). In the International Classification of Crime for Statistical Purposes 1.0 (https://unstats.un.org/unsd/statcom/doc15/BG-ICCS-UNODC.pdf), drawn by the UNODOC in 2015, femicide is characterized as "[...] the intentional killing of a woman for misogynous or gender-based reasons" (p. 32).

3 ISTAT is the Italian National Institute for Statistics (https://www.istat.it); the 2019 report on GBV can be consulted here: https://www.istat.it/it/archivio/ 235994.

4 http://www3.weforum.org/docs/WEF_GGGR_2018.pdf. The 2021 Gender Gap Report can be downloaded here: https://www.weforum.org/reports/ global-gender-gap-report-2021. It does not give back a quite different picture from its homologous of 2018, which we consulted while writing the first version of this paper.

${ }^{5}$ In an Italian context, the debate on gendered language has been opened by Alma Sabatini's seminal leaflets (Sabatini 1986, 1993). A more recent volume contributing to this field is Somma and Maestri (2020), which critically rethinks of Sabatini's leaflets more than 30 years after her groundbreaking work.
} 
perception studies exploring whether different grammatical constructions imply different responsibility attributions on the readers' part. Our hypothesis was that readers were more prone to attribute responsibility to perpetrators in events described with active constructions and constructions in which perpetrators are overtly expressed.

The paper is structured as follows. Section 2 frames argument structure and nominal constructions within a cognitive approach and describes their effects on readers' discourse perception. Section 3 reports on the methodology and results of the corpus study. Sections 4 and 5 contain the methodology and results of two related perception studies. In Section 6, the results of both analyses of Sections 4 and 5 are jointly discussed. Finally, Section 7 offers brief concluding remarks.

\section{Argument structure constructions}

\subsection{Argument structure constructions in theory}

In cognitive approaches (Goldberg, 1995; Langacker, 2006; Croft, 2012), constructions are understood as units pairing form with meaning. Constructions can be filled by certain lexemes, which share a degree of semantic solidarity both with other lexemes filling the construction and with the abstract meaning of the construction itself. Among constructions, the subclass of argument structure constructions is highly relevant for humans' conceptualization and interpretation of reality, as it "provides the basic means of clausal expressions" (Goldberg, 1995: 3). As CDA analysts put it, "transitivity ... is the way the clause is used to analyze events and situations as being of certain types" (Fowler, 1991: 71).

In Cognitive Linguistics, events are understood as relationships among entities, i.e., participants, that interact with one another (Langacker, 2006: 116-117). Crucially, language users have different options, that is, construals, to describe the same event/relationship among entities (Croft, 2012: 13). Construal operations account for the different ways that humans have to talk about the same events, which leads to categorize events and situations in certain ways and not in others. "It is precisely because of their conceptual import - the contrasting images they impose - that alternative grammatical devices are commonly available to code the same situation" (Langacker, 1991: 295). Though construals may refer to the same relationship, they give prominence to, or profile, different participants or aspects of it, as illustrated in Fig. 1a-c (adapted from Langacker, 2006: 119). ${ }^{6}$

(a) violentare

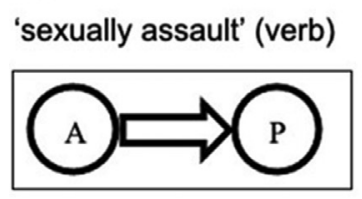

(b) violentatore

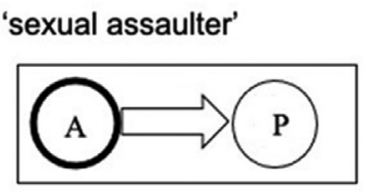

(c) violenza

\section{'sexual assault' (noun)}

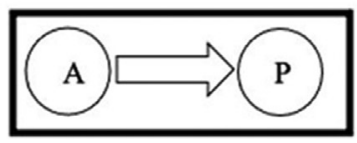

Fig. 1. Same event, different profiles.

In Fig. 1a, violentare profiles a relationship in which an agent $(A)$ intentionally exercises violence upon a patient $(P)$. In Fig. 1b, the agent noun violentatore only profiles the A, while backgrounding other aspects of the event. In Fig. 1c, the action noun violenza profiles an abstract entity obtained by conceptual reification (Dunmire, 2007; van Dijk, 2008a; Sansò, 2016), while backgrounding the participants in the event and the actual relationship between them. ${ }^{7}$ For this reason, action nominals are said to carry an inherent mystifying potential upon addressees (Fowler, 1991).

Despite having the same profile, relationships can be conceptualized from different perspectives, which in turn has consequences in terms of salience, as represented by the grey-filled shapes in Fig. 2a-c:

(a) violentare 'sexually assault'

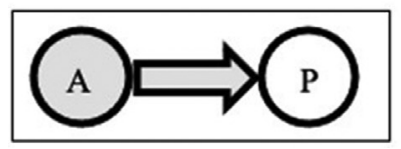

(b) subire [violenza] 'undergo sexual assault'

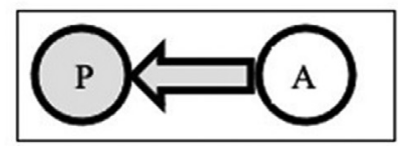

(c) essere violentato/a

'be sexually assaulted'

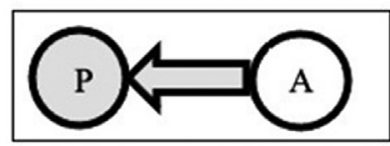

Fig. 2. Same profile, different perspectives.

The active verbal expressions in Fig. $2 \mathrm{a}-\mathrm{b}$ profile the same relationship. However, the relationship is mentally accessed via the agent in Fig. $2 a$ and via the patient in Fig. $2 b$. The same relationship is likewise accessed via the patient with a passive

\footnotetext{
${ }^{6}$ In all figures included in this paper, circles indicate participants, arrows represent relationships, and thicker lines highlight profiles. The linguistic expressions in Figs. 1-3 are adapted from actual examples of our corpus.

7 Expressions such as ha usato violenza, which literally means '(someone) used violence', and other light verb constructions (see Section 3), have been considered altogether and we annotated them as verbal constructions.
} 
construction (Fig. 2c). The expressions in Fig. 2a and in Fig. 2b-c respectively highlight the agent's activity and the core process which the patient thereby undergoes (Langacker, 2006: 127). Sansò (2006: 267) contrasts A-oriented (e.g. Fig. 2a) with P-oriented (Fig. $2 \mathrm{~b}-\mathrm{c}$ ) events, the latter being characterized by high topical Ps and discourse peripheral, though easily recoverable As. In fact, psycholinguistic research has demonstrated that voice selection can guide the addressees toward conceptualizing the agent or the patient as the primary actor in the event (Clark and Begun, 1968; Johnson-Laird, 1977; Tannenbaum and Williams, 1968; Turner and Rommetveit, 1968; see also Rueschemeyer and Gaskell, 2018: ch. 22). Thus, pragmatic factors such as prominence and perspective prove to be pivotal for the characterization of argument structure constructions (Langacker, 2006; Sansò, 2006, 2016; De Cesare, 2007).

Similar images as those in Figs. 1 and 2 can model other argument structure constructions, such as the anticausative, the reflexive, and the reciprocal constructions of Fig. $3 a-c .^{8}$

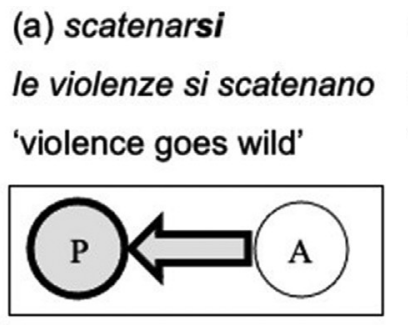

(b) scatenarsi

l'uomo si scatena 'the man goes wild'

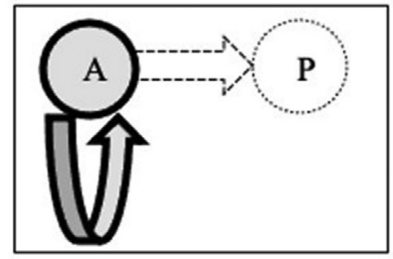

(c) picchiarsi

$$
\text { si picchiano }
$$

\section{'they beat one another'}

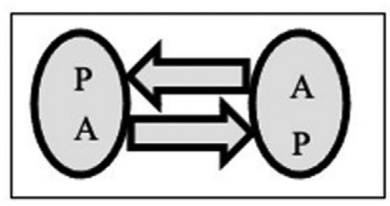

Fig. 3. Representing anticausative, reflexive, and reciprocal constructions.

The anticausative construction in Fig. 3a depicts the event as a bare happening: the second participant of a causal transitive verb (such as violenze in scatenare le violenze '[lit.] make violence wild') becomes the sole participant of a noncausal intransitive verb. This change is usually signaled by morphological material in Italian, specifically by the reflexive marker si (Sansò, 2006; on anticausatives and the coding of causal vs. noncausal events, see also Haspelmath, 2014; on anticausatives in Italian, see Cennamo, 2012, 2015). The profile of 3a does not include the instigator of the event: violence is described as an entity that spontaneously transits from a state of non-being into a state of being. Thus, passives and anticausatives are both Poriented, but they differ in that they respectively background and suppress the agent. Sansò (2006) also argues that anticausative constructions conceptualize events as naked facts in a holistic fashion; in this respect, anticausatives are also functionally close to action nominals. As represented in Fig. 3b, reflexive constructions are used to describe events in which a participant, typically an agent, is simultaneously the initiator and the endpoint of an event (Croft, 2012: 236), which can optionally include another participant (l'uomo si scatena contro la compagna 'the man goes wild against his partner'). The dashed arrow and patient participant of Fig. 3b model such optional patient participant. Reciprocal constructions (Fig. 3c) depict situations that feature at least two participants that are in an identical reverse relation to each other and perform two identical semantic roles each (Kemmer, 1993: 95-127).

\subsection{Argument structure constructions in (discursive) practice}

In Section 2.1, we discussed how, in theory, argument structure constructions differ in terms of construal, by assigning varying prominence to different aspects of and participants in events, named profiles, and representing the profiles from varying perspectives. Therefore, the intentional or routinized selection of one construal over another one in discourse can have the (unwitting) effect of profiling or backgrounding certain aspects of the depicted event (Fowler, 1991: 71;van Dijk, 2008b). As Hart (2011, 2018a) has pointed out, construals can be crucial to categorize events and situations and, in the specific case of GBV, to diminish perpetrators' responsibility for the femicide, by suppressing and backgrounding them in discourse or by representing the event as a bare happening (Tranchese and Zollo, 2013; Pinelli and Zanchi, 2021).

Concrete discursive usages of each construction presented in Section 2.1 outline a more intricate picture. In Section 2.1 (Fig. 2a-b), we have seen that active transitive constructions can be used to encode opposite events in terms of perspective, owing to the meaning of the verb instantiating the construction, e.g. violentare 'sexually assault' and subire 'undergo'.

In fact, since Hopper and Thompson's (1980) seminal work, transitivity in discourse is acknowledged to be a scalar notion, which varies according to a number of parameters including (a) the number of linguistically expressed participants; (b) the agent's degree of agentivity and intentionality; (c) the patient's degree of affectedness and individuation.

\footnotetext{
${ }^{8}$ As Fig. 3 represents three less obvious argument structure constructions, we added examples for each of them. Examples from our corpus are reported in Section 3.2. Note that, in Italian, these three different constructions can be marked through the same morpheme si, which is also used to encode passives and impersonals (e.g. Cennamo, 2012, 2015).
} 
Concerning parameter (a), for example, two-place verbs can be used intransitively: these usages do not profile the patient, thus making transitive verbs closer to intransitive ones in discourse ${ }^{9}$ :

(1) a....spara all'ex moglie (GSApr2019)

'... [he] shoots his ex-wife'

b. ...ha estratto la pistola e ha sparato (GSApr2019)

'...he pulled out his gun and fired [it].'

c. ...ieri pomeriggio il 48enne sarebbe uscito di casa (GSNov2018)

'...yesterday afternoon the 48-year-old man allegedly left home'

a.

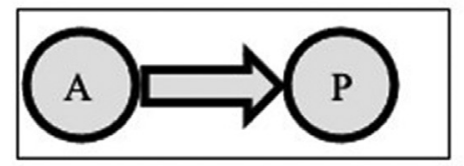

b.

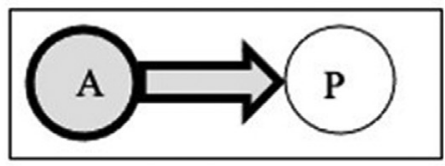

c.

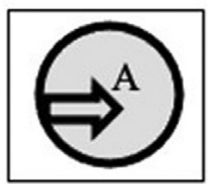

Fig. 4. Transitivity in discourse.

Example (1)a (Fig. 4a) contains the two-place verb sparare. The patient 2nd participant is expressed by the full PP all' ex moglie. Example (1)b (Fig. 4b), from the same report as (2)a, contains an analytic past form of the same verb. The patient is obviously present in the reality, but it is not linguistically expressed and, thus, not profiled. Therefore, the profile of example (1)b includes a single participant, as holds for (1)c (Fig. 4c), which features an intransitive motion verb, uscire. ${ }^{10}$

Note that the sole participant in the event expressed through the intransitive construction of (1)c is a sentient human entity, an agent. In an intransitive construction, however, an action nominal can also occupy the same argument slot, as in (2), where aggressione is the sole participant of the intransitive verb avvenire.

(2) La drammatica aggressione è avvenuta lunedì pomeriggio (PPJan2019)

'The dramatic aggression occurred on Monday afternoon.'

The construction in (2) is probably employed to introduce the setting of the GBV event but has nevertheless the side-effect of representing the aggression as something that occurred. Thus, this active intransitive construction has a profile similar to the anticausative (Fig. 3a).Finally, while analyzing constructional usages in discourse, one should take into account how the prominence and perspective effects inherent to each argument structure construction interact with the concrete way participants are referred to in discourse. For example, given that the passive construction allows for the omission of agents, their explicit mention through an oblique phrase must suggest saliency in discourse. The same holds for nominal constructions of the type of aggressione 'aggression': the overt expression of participants through adnominal modifiers is optional, and therefore their overt mention must indicate saliency as well.

\section{Responsibility attribution in GBV reports: a corpus study}

\subsection{Data and methodology}

To investigate argument structure constructions in Italian GBV reports, we compiled a corpus (GBV Corpus) of 40 articles from four Italian local daily newspapers: L'Eco di Bergamo (EB) and La Provincia Pavese (PP), published in Northern Italy, and Corriere Adriatico (CA) and Gazzetta del Sud (GS), published in Central and Southern Italy. ${ }^{11}$ From each newspaper we selected ten articles using keywords such as femminicidio 'femicide' and violenza contro le donne 'violence against women'. We included in GBV Corpus only news reports in which perpetrators' guilt was certain.

Using UAM Corpus Tool (http://www.corpustool.com) we annotated the GBV Corpus according to an ad hoc-built annotation scheme. ${ }^{12}$ We tagged all constructions denoting events in which perpetrators perform actions related to GBV, presumably exercising intentionality and control. By contrast, we did not annotate events with the victim as a principal initiator. Thus, sentences such as il sessantenne aveva tentato di strangolarla 'the 60-year-old man had tried to strangle her' (EBNov2018)

\footnotetext{
${ }^{9}$ Examples in (1) are taken from our corpus. Abbreviations are explained in Section 3.1.

10 In Fig. 4c, the arrow represents the temporal unfolding of the event, which is not a state like the 48-year-old was out of his home. The arrow lies inside the circle as the denoted event is not directed toward any other entity (see Langacker, 2006 for details).

11 We opted for local newspapers as we assumed the latter to be transversal among people of different social strata. Moreover, we expected local newspaper to have fewer human resources to carefully apply the Italian guidelines concerning the representation of GBV, known as Manifesto di Venezia. With this in mind, we selected a geographically balanced sample of newspapers with a reasonably great circulation in their relative areas (cf. fn. 5-8 in Pinelli and Zanchi, 2021).

12 UAM Corpus Tool has been created and is maintained by Mick O'Donnell. For the present analysis we used the version 2.8 (the User manual is included in references as O'Donnell, 2008, 2012).
} 
and $i$ comportamenti dispotici erano peggiorati 'despotic behavior had worsened' (EBNov2018) are annotated, whereas sentences such as la donna è riuscita a sottrarsi alle percosse 'the woman managed to escape from beating' (CAJune2016) are not. Table 1 displays the annotated constructions, an example for each of them, and its translation.

Table 1

Annotated constructions with examples.

\begin{tabular}{lll}
\hline Construction & Example & Translation \\
\hline 1. Active & il sessantenne aveva tentato di strangolarla & the 60-year-old man had tried to strangle her \\
2. Causative & fa prostituire la compagna & (he) forces (his) partner into prostitution \\
3. Reflexive & si sarebbe scagliato... contro la convivente & (he) allegedly hurled himself against (his) spouse \\
4. Passive & è stata con forza caricata in auto dall'uomo & (she) has been forcefully loaded into the car by the man \\
5. Anticausative & la furia omicida si è scatenata & the murderous fury has raged \\
6. Reciprocal & i due hanno iniziato a discutere & the two began to discuss \\
7. Nominal & aggressione del 28enne ai danni della moglie 26enne & assault of the 28-year-old man against (his) 26-year-old wife
\end{tabular}

Besides the construction type, we annotated the argumental participants, i.e., participants encoded as part of verbal valency, and the victim and the perpetrator even if expressed by non-argumental participants (for example, we annotated the perpetrators when expressed by agents of passive verbs; cf. dall'uomo 'by the man' in Table 1, example 4). For each annotated construction, that is, for each annotated textual passage, participants were assigned a tag for their role in reality, their linguistic expression, and their semantic role. ${ }^{13}$ Fig. 5 shows the annotation scheme:

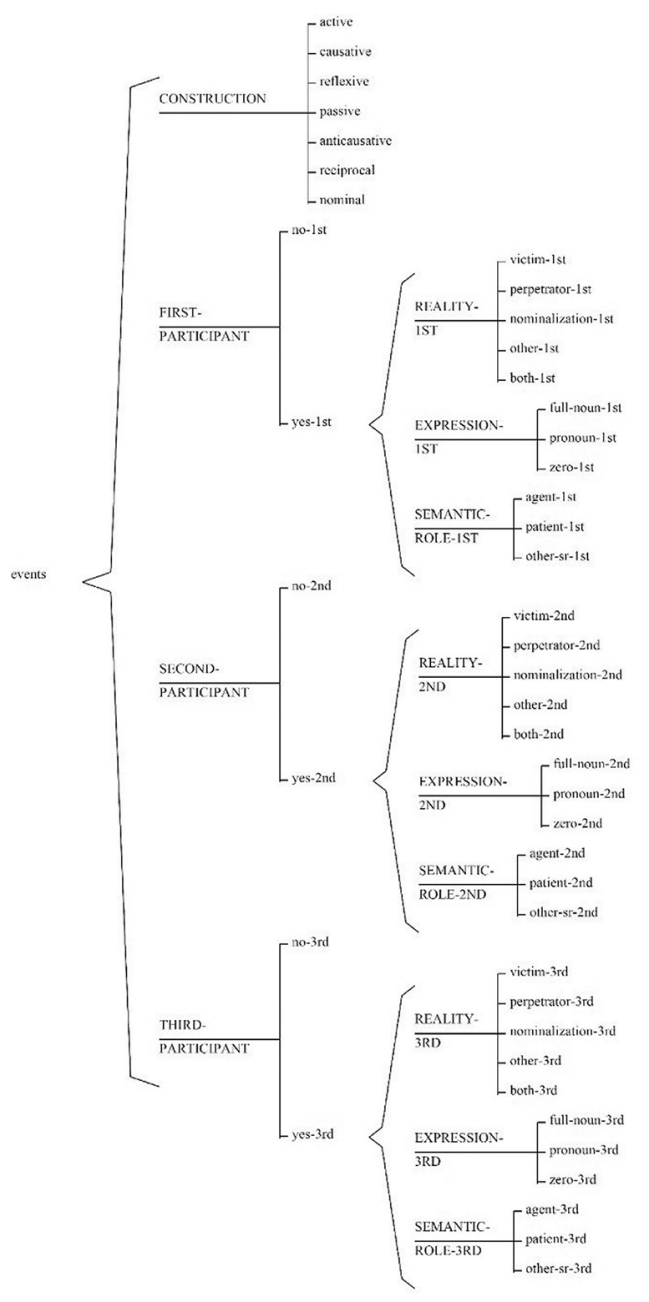

Fig. 5. Annotation scheme.

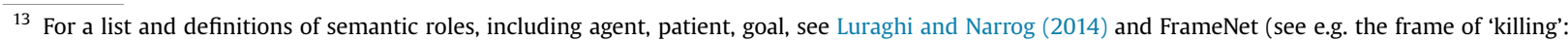
https://framenet.icsi.berkeley.edu/fndrupal/framelndex).
} 
The semantic role annotation was coarse-grained: the labels "agent" and "patient" are given to agents and patients proper and also to agent-like and patient-like participants. Agent-like and patient-like participants share with agents and patients proper some, but not all, semantic features, such as animacy (e.g. in Table 1, example 3, contro la convivente is properly an animate goal participant, which is nevertheless given the label 'patient'). When two PPs modify a nominal construction (e.g. Table 1, example 7), the participant expressed by the lighter PP is annotated as a 1st participant (del 28enne), the participant encoded with the heavier PP as a 2nd participant (ai danni della moglie 26enne). Constructions containing a light or a modal verb (e.g. tentare di 'try to', iniziare a 'begin to') count one event (Table 1, examples 1 and 6), whereas coordinated verbs count two events. ${ }^{14}$

(3) L'uomo... ha accoltellato e ucciso la consorte.

'The man...stabbed and killed his wife.'

(CAFeb2019)

In (3), the perpetrator and the victim are expressed by two NPs that function as a shared subject and object of two coordinated verbs. Both are tagged twice, once as full nouns and once as zeros.

The annotation process was independently performed by two annotators, who later compared, discussed, and found an agreed annotation. Originally, the inter-coder agreement scored at 88\%. Both annotators overlooked a number of relevant examples and misused labels. The major differences between the two annotators were the following:

(a) The former annotator tagged active intransitive verbs with noncausal semantics as anticausatives (e.g. $i$ comportamenti dispotici erano peggiorati 'despotic behavior had worsened' [EB Nov 2018]); despite their functional similarity, only verbs that have a basic causal usage can have an anticausative counterpart and accordingly be given the anticausative label (in this respect, compare l'uomo ha scatenato la furia omicida 'the man has raged a murderous fury' with example 5, Table 1);

(b) Only the latter annotator tagged events undergone by entities belonging to victims' personal sphere and events narrated in direct speeches (both are included in the final annotation).

\subsection{Corpus study}

For the present study we annotated and analyzed 720 events. Table 2 contains the results of the final annotation ordered by frequency.

Table 2

\begin{tabular}{ll} 
Final annotation results. & \\
\hline Construction & Final \\
\hline Active & $343(47.6 \%)$ \\
Nominal & $249(34.6 \%)$ \\
Passive & $75(10.4 \%)$ \\
Anticausative & $24(3.3 \%)$ \\
Reflexive & $19(2.6 \%)$ \\
Causative & $7(1 \%)$ \\
Reciprocal & $3(0.5 \%)$ \\
TOTAL & $\mathbf{7 2 0 ( 1 0 0 \% )}$ \\
\hline
\end{tabular}

This section examines the results regarding the three most frequent constructions in the GBV Corpus, i.e., actives (3.2.1), passives (3.2.2) and nominal constructions (3.2.3), which were also taken into account in the perception studies (Sections 4 and 5). The remaining annotated constructions, i.e. anticausatives, causatives, reciprocals, and reflexives, are discussed in relation to the mainly attested constructions, as they proved to cover similar functional domains with them.

\subsubsection{Active constructions and their participants}

Active constructions can trigger quite varied conceptualizations of the same event depending on the verbs instantiating them, their participants, and the overall degree of transitivity of the denoted event (see Section 2).

Table 3 contains data concerning the three most frequent first participants of active constructions, which are paramount as they constitute the mental access point to the denoted event (Section 2.1).

\footnotetext{
14 Light verbs (also called verbi supporto 'support verbs') are semantically weak verbs with an empty argument structure that combine with other elements, usually nouns, such as fare 'do' in the Italian light verb construction fare una telefonata 'make a phone call' (vs. telefonare, which is a heavy verb with the same meaning) (see e.g. Jezek 2004).
} 
Table 3

First participants of active constructions.

\begin{tabular}{ll}
\hline Active constructions & 1st participant \\
\hline Perpetrator & $265(77.2 \%)$ \\
Nominal & $44(12.8 \%)$ \\
Victim & $29(8.4 \%)$ \\
Other & $4(1.1 \%)$ \\
Both & $1(0.2 \%)$ \\
TOTAL & $\mathbf{3 4 3 ( 1 0 0 \% )}$ \\
\hline
\end{tabular}

Table 3 shows that the first participant of active constructions was most frequently the perpetrator, who always played the role of agent (265/343, viz. $77.2 \%$ ). The 2 nd argument slot can be taken by different participants or left unexpressed, resulting in different degrees of transitivity.

Prototypically transitive events, that is, events in which an intentional agent causes a change of state upon a linguistically expressed patient (Section 2.1 ), were only $235 / 343 .{ }^{15}$ In these passages, the patient(-like) role was played by the victim:

(4) Picchia e minaccia convivente per anni

' $[\mathrm{He}]$ has hit and threatened the cohabitant for years.'

(EBNov2018)

In (4) the construction profiles both participants and is instantiated by verbs that denote highly transitive events with volitional agents and highly affected patients, specifically, picchiare 'beat' and minacciare 'threaten'. ${ }^{16}$

By contrast, in four passages containing transitive verbs used intransitively or intransitive verbs, the agent-perpetrator was the only participant profiled (see the discussion of examples (1)a-b in Section 2.2). ${ }^{17}$ In passages such as (1)b, the transitive verb is used intransitively, thus making the overall denoted event less transitive (Hopper and Thompson, 1980).

Similarly, in 26 active constructions, the victim was not mentioned as related to the construction itself but only elsewhere in the text, and the second participant of the construction was a noun phrase, as in (5):

(5) Ha vibrato una ventina di fendenti che non le hanno lasciato scampo

' $[\mathrm{He}]$ vibrated about twenty slashes that did not give her a way out.'

(PPMay2019)

In (5), the referent denoted by the noun fendenti, taken as object by the verb ha vibrato in the main clause, in turn plays the role of agent in the relative clause containing the verb lasciare scampo, which has the victim as a second argument. ${ }^{18}$

A number of active constructions (44/343, viz. 12.8\%) were instantiated by intransitive verbs taking nominals as first participants. These constructions result in a low degree of transitivity, as shown in (6).

(6) ...i comportamenti dispotici erano peggiorati.

'.... despotic behavior had worsened over time.'

(EBNov2018)

In (6), due to the NP $i$ comportamenti dispotici and the noncausal verb peggiorare, the event is represented as a bare happening. This type of active constructions is functionally similar to morphological anticausatives (24/720 events, viz. 3.3\%, cf. Table 2), whereby the GBV is described as a spontaneous event (see Table 1, example 5).

Finally, the victim can also occur as a first participant of an active construction (29/343 events, viz. 8.4\%): due to the meaning of the instantiating verbs, the victim either plays the role of patient with transitive verbs such as subire 'suffer' in (7) or a patient-like role with intransitive verbs such as scomparire 'disappear.' ${ }^{19}$

(7) ...ai danni della malcapitata giovane ascolana che ha subito, inerme, le percosse del suo fidanzato.

'...against the unfortunate young woman from Ascoli who suffered, defenseless, her boyfriend's blows.'

(CAJan2019)

\footnotetext{
${ }^{15}$ This count only includes active forms in which both the agent and the patient are linguistically expressed (prototypically transitive events). Since cases in which the victim is syntactically a $3^{\text {rd }}$ patient(-like) participant (e.g. procurandole una frattura scomposta 'giving her a compound fracture') are similar to transitive events from the functional perspective of profiling/backgrounding perpetrators and victims, they are included in the count. For the same reason, causatives ( 7 events) and reflexives (7 events) with overt agent-perpetrator and patient-victim should be added (see Table 7).

${ }^{16}$ Italian is a pro-drop language, in which topical subjects are by default omitted. In (4) the pronominal subject that refers to the perpetrator is omitted, but the subject is marked on the third person verbal form. The expression vs. omission of the pronoun can also play a role in focusing or defocusing participants: if a participant that is by default omitted is expressed, that participant must be particularly salient in discourse. This point was not taken into consideration in the present study.

${ }^{17}$ For the general count of functionally similar constructions in terms of perpetrators' profiling/backgrounding, reflexives with no overt expression of patient-victims (11 events) should be added.

${ }^{18}$ In GBV corpus we counted four active constructions in which the agent is played by an entity other than the perpetrator, such as fendenti in (5).

19 One functionally similar reflexive event with the victim expressed as a first participant should be added to this count (se lo ritrovava davanti '(she) found herself in front of him' PPJuly2018).
} 
As with passives, the active constructions with the victim as a first participant profile the event from the patient's viewpoint, thus highlighting the core process undergone by the patient rather than agents' activities (Section 2.1). Moreover, when the second participant is a nominal, as percosse in (7), the construction has paramount discursive consequences. While passive constructions instantiated by the corresponding passive verb (e.g. essere percossa 'be beaten') directly refer to the violence as a process, in active constructions with a nominal as a second participant, the event is reified as an abstract entity: this occurred in 17/29 (58.6\%) active events with the victim as first participant. Moreover, while passive constructions allow to represent perpetrators as agents proper (e.g. essere percossa dal fidanzato 'be beaten by her boyfriend'), this type of active constructions does not. The perpetrator is mentioned as an optional adnominal NP only in three passages, and he was not construed as an agent proper, but as a possessor, as del suo fidanzato in (7).

\subsubsection{Passive constructions and their participants}

We now present the analysis of passive constructions that, as discussed in Section 2.1, profile the core process that the patient thereby undergoes.

\begin{tabular}{ll} 
Table $\mathbf{4}$ \\
First participants of passive constructions. \\
\hline Passive constructions & \\
\hline Victim & 1st participant \\
Nominal & $56(74.6 \%)$ \\
Other & $16(21.3 \%)$ \\
TOTAL & $3(4 \%)$ \\
\end{tabular}

As shown in Table 4, passive constructions most frequently take the victim as a first participant (56/75, viz. $74,6 \%$ ). She always played the role of patient, as in (8)-(9).

(8) Picchiata brutalmente dal fidanzato all'alba del primo dell'anno.

'[She was] brutally hit by [her] boyfriend at dawn on New Year's Day.'

(CAJan2019)

(9) Lo scorso luglio la donna era stata scaraventata a terra, al culmine di un violento litigio. 'Last July, the woman had been thrown to the ground at the height of a violent argument.' (EBNov2018)

As passives are a P-oriented construction (Section 2.1), they conceptualize an event that has the patient-victim as a mental access point. This constructional feature of passives interacts with the discourse properties of passive agents (Section 2.2). As a valency decreasing strategy, passives allow for agents' omission: as non-obligatory participants, passive agents must be discursively salient when overt. In GBV Corpus, in 14/56 (viz. 25\%) passive constructions with the victim as a first participant, the perpetrator was overtly expressed and encoded as an agent, as in (8), whereas in 38/56 events (viz. 67.8\%) the passive was agentless, as in (9). ${ }^{20}$

Besides the victim, the first slot of passive constructions could be occupied by nominals (16/75 events, viz. 21.3\%), as in (10).

(10) ...per segnalare aggressioni e violenze compiute da parte del coniuge.

'...to report assaults and abuses perpetrated by [her] husband.'

(CAOct2017)

Again, nominals, such as aggressioni e violenze in (10), profile a reified entity rather than a process (as, instead, do the corresponding verbs aggredire 'assault' and violentare 'sexually assault'). Moreover, in passive constructions with nominals as first participants, passive agents are more frequently omitted, as in (11) (11/16, viz. 68.8\%), rather than expressed, as in (10) (4/ 16, viz. $31.2 \%)^{21}$

(11) La donna si era dovuta rivolgere al Pronto Soccorso per le botte patite.

'The woman had to go to the emergency room because of the suffered blows.'

(EBNov2018)

Passive events in which the first slot was occupied by other nouns (3/75 events, viz. 4\%), as (12), are always agentless:

(12) ...per la vittima a cui era stato sottratto anche il relativo cellulare.

'...for the victim, who was also deprived of [her] cell phone.'

(EBFeb2017)

\footnotetext{
${ }^{20}$ In the remaining four passives, the agent is played by another entity (see (13)).

21 In a single passage (Due colpi di arma da fuoco sparati da un revolver 'Two gunshots shot by a revolver' GSApr2019), the agent is possibly another entity, i.e. the revolver, which however might be also analyzed as a source.
} 
Table 5 summarizes data concerning passive agents in GBV Corpus.

Table 5

Passive agents.

\begin{tabular}{lll}
\hline Omitted agent & Expressed agent & \\
\cline { 2 - 3 } & Perpetrator & Other entity \\
\hline $52(69.3 \%)$ & $18(24 \%)$ & $5(6.6 \%)$ \\
\hline
\end{tabular}

Finally, perpetrators' backgrounding was also achieved by encoding other entities, such as instruments, as agents. This is the case of da un pugno in (13):

(13) ...era stata colpita da un pugno alla schiena.

'...[she] was hit by a punch in her back.'

(EBNov2018)

\subsubsection{Nominal constructions and their participants}

Nominal constructions ${ }^{22}$ discursively reify the event and background participants' relationship (Section 2.1). This is confirmed by the fact that, as displayed in Table 6, the participants in the event were most frequently $(196 / 249$, viz. $78.8 \%)$ omitted with these constructions.

Table 6

Participants of nominal constructions.

\begin{tabular}{|c|c|c|c|}
\hline Nominal constructions & 1st participant & 2nd participant & Total \\
\hline Victim & 16 & 3 & $19(7.6 \%)$ \\
\hline Perpetrator & 19 & 1 & $20(8 \%)$ \\
\hline Other & 12 & - & $12(4.8 \%)$ \\
\hline Both & 6 & - & $6(2.4 \%)$ \\
\hline None & 196 & & $196(78.7 \%)$ \\
\hline TOTAL & 249 & & \\
\hline
\end{tabular}

However, as with passive agents (Section 3.2.2), we can say that, since optional, the expression of participants tends to put them under focus. Only in 20/249 (viz. 8\%) of nominal constructions, the perpetrator was mentioned. Furthermore, as discussed in Section 3.2.1, even if mentioned, the perpetrator was encoded as an agent proper only in 6/249 (viz. 2.4\%) events, as in (14), while as a possessor in 14/249 (viz. 5.6\%) events, as in (15), in which the heavier PP was used to codify the victimpatient.

(14) ...era stata vittima di una violenta aggressione da parte del suo ex compagno.

'... [she] was victim of a violent assault on her former partner's part.'

(CAMar2014)

(15) ...dopo l'ennesima aggressione del 28enne ai danni della moglie 26enne.

'....after the umpteenth assault of the 28-years-old man against his 26-years-old wife.'

(EBOct2018)

Finally, it is interesting to describe nominal constructions in which both the victim and the perpetrator were mentioned conjunctively: both participants played the same role each and, thus, agentivity was equally assigned to both of them, as in (16).

(16) Prima un acceso litigio tra $i$ due fidanzati...

'At first a heated fight between the two partners...'

(CAJan2019)

This is similar to what happens in reciprocal constructions (3/720 events, viz. $0.42 \%$ ), in which the two participants play the same semantic role each, and are attributed the same agentivity, as in (17). ${ }^{23}$

\footnotetext{
$\overline{22}$ Contrary to what can be expected, nominal constructions mainly appeared in the body of newspaper articles. Only 13/249 occurrences were found in headlines and 7/249 in subheads.

${ }^{23}$ Similarly, in one active event the victim and the perpetrator are both 1st patient participants (entrambi hanno riportato lievi contusioni PPJuly2017 'both suffered minor contusions'), thus depicted as similarly affected by the reported event.
} 
(17) ...genitori che stavano litigando violentemente '... parents, who were vehemently fighting.' (CAFeb2018)

\subsection{Overall results of the corpus study}

The analysis of Section 3.2 shows that different constructions can describe the same event from different perspectives. Moreover, the overall process, its participants, and their relation can be profiled, backgrounded or suppressed. In this section, we propose to directly correlate two scalar values, specifically, the degree of agentivity and transitivity, on the one hand, and the degree of responsibility attributed to perpetrators, on the other. We ordered the attested constructions along a continuum of agentivity/responsibility, which we carved up into three macro-values, whose corresponding constructions and characteristics are summarized in Table 7.

Table 7

Correlation between the degree of transitivity/agentivity and responsibility.

\begin{tabular}{|c|c|c|c|c|}
\hline $\begin{array}{l}\text { Agentivity/ } \\
\text { responsibility }\end{array}$ & Constructions & Examples & Freq. & Total \\
\hline \multicolumn{5}{|l|}{ High } \\
\hline $\begin{array}{l}\text { A-oriented; overt } \\
\text { agent-perpetrator }\end{array}$ & $\begin{array}{l}\text { - Active/causative/reflexive, 1st part.: } \\
\text { agent-perpetrator, 2nd/3rd part.: pa- } \\
\text { tient-victim } \\
\text { - Active/reflexive, 1st part.: } \\
\text { agent-perpetrator, victim-patientless }\end{array}$ & $\begin{array}{l}\text { - L'uomo ha aggredito la convivente } \\
\text { 'The man assaulted the cohabitant' } \\
\text { - L'uomo ha estratto un coltello } \\
\text { 'The man pulled out a knife' }\end{array}$ & $\begin{array}{l}249 \\
41\end{array}$ & $290(40.2 \%)$ \\
\hline \multicolumn{5}{|l|}{ Middle } \\
\hline $\begin{array}{l}\text { A-oriented; perpetrator } \\
\quad \neq \text { agent }\end{array}$ & - Active, 1st part.: agent-other entity & $\begin{array}{l}\text { - Un pugno le ha fratturato il setto nasale } \\
\text { 'A punch fractured her nasal septum' }\end{array}$ & 4 & $49(6.8 \%)$ \\
\hline $\begin{array}{l}\text { P-oriented; overt } \\
\text { agent-perpetrator }\end{array}$ & $\begin{array}{l}\text { - Passive, 1st part.: patient-victim/ } \\
\text { nominal, 2nd/3rd part.: agent- } \\
\text { perpetrator } \\
\text { - Active/reflexive, 1st part.: patient- } \\
\text { victim, 2nd part.: perpetrator/other } \\
\text { entity }\end{array}$ & $\begin{array}{l}\text { - La donna è stata picchiata dal compagno } \\
\text { 'The women was hit by [her] partner' } \\
\text { - La donna riceveva minacce dall'ex-marito } \\
\text { 'The woman have received threats by [her] } \\
\text { ex-husband' }\end{array}$ & $\begin{array}{l}18 \\
11\end{array}$ & \\
\hline Symmetric & $\begin{array}{l}\text { - Reciprocal/active/nominal, 1st part.: } \\
\text { agent/patient-both }\end{array}$ & $\begin{array}{l}\text { - I due hanno iniziato a litigare } \\
\text { 'The two started fighting' }\end{array}$ & 10 & \\
\hline $\begin{array}{l}\text { Reified nominals; overt } \\
\text { agent-perpetrator } \\
\text { Low }\end{array}$ & - Nominal, overt agent-perpetrator & $\begin{array}{l}\text { - Dopo l'ennesima aggressione da parte dell'uomo... } \\
\text { 'After the umpteenth assault on [her] partner's part...' }\end{array}$ & 6 & \\
\hline $\begin{array}{l}\text { P-oriented; perpetrator } \\
\quad \neq \text { agent }\end{array}$ & $\begin{array}{l}\text { - Passive, 1st part.: patient-victim/ } \\
\text { nominal/other, 2nd: agent-other } \\
\text { entity } \\
\text { - Active, 1st part.: patient-victim, 2nd } \\
\text { part.: nominal, 3rd part.: possessor- } \\
\text { perpetrator }\end{array}$ & $\begin{array}{l}\text { - La donna era stata colpita da un pugno } \\
\text { 'The woman was hit by a punch' } \\
\text { - La donna ha subito le percosse del fidanzato } \\
\text { 'The woman suffered her boyfriend's blows' }\end{array}$ & $\begin{array}{l}5 \\
3\end{array}$ & $381(53 \%)$ \\
\hline $\begin{array}{l}\text { Reified nominal; } \\
\quad \text { perpetrator } \neq \text { agent }\end{array}$ & $\begin{array}{l}\text { - Nominal, 1st part.: possessor- } \\
\text { perpetrator }\end{array}$ & $\begin{array}{l}\text { - Dopo l'ennesima aggressione dell'uomo... } \\
\text { 'After the umpteenth assault of the man...' }\end{array}$ & 14 & \\
\hline P-oriented; agentless & $\begin{array}{l}\text { - Passive, 1st part.: patient-victim/ } \\
\text { nominal/other, perpetrator-agentless } \\
\text { - Active, 1st part.: patient-victim, 2nd } \\
\text { part.: nominal/other entity, perpe- } \\
\text { trator-agentless }\end{array}$ & $\begin{array}{l}\text { - La donna è stata uccisa } \\
\text { 'The woman was killed' } \\
\text { - La donna è stata vittima di violenze } \\
\text { 'The woman was victim of violence' }\end{array}$ & $\begin{array}{l}52 \\
16\end{array}$ & \\
\hline $\begin{array}{l}\text { Reified nominal; } \\
\text { agentless }\end{array}$ & - Nominal, perpetrator-agentless & - Maltrattamenti e lesioni & 223 & \\
\hline Bare happening & $\begin{array}{l}\text { - Active, 1st part.: nominal } \\
\text { - Anticausatives }\end{array}$ & $\begin{array}{l}\text { - I comportamenti dispotici erano peggiorati } \\
\text { 'Despotic behavior had worsened over time' } \\
\text { - Le violenze si erano aggravate } \\
\text { 'Violence had worsened over time' }\end{array}$ & $\begin{array}{l}44 \\
24\end{array}$ & \\
\hline Total & & & & 720 (100\%) \\
\hline
\end{tabular}


Agent-oriented constructions, such as actives, reflexives and causatives, correspond to a high degree of agentivity and transitivity, thus of responsibility, as these events are accessed through the perspective of the overtly expressed Agentperpetrator. The second macro-value corresponding to the middle degree of agentivity/responsibility has a more varied structure. It includes different constructions: a) Agent-oriented constructions, such as actives and reflexives, in which the Agent is not the perpetrator; b) Patient-oriented constructions, such as passives, or other constructions that reify the event, such as nominalizations, in which the Agent-perpetrator is overtly expressed; c) Symmetric constructions in which both the victim and the perpetrator play identical and reverse roles each in the event and agentivity is equally assigned to both of them. Lastly, the following constructions correspond to the low degree of agentivity/responsibility: a) Patient-oriented constructions, such as passives, in which the perpetrator does not play the role of agent or is not overtly expressed (to this group also belong actives in which the Patient-victim is the first participant); b) Reifying constructions, such as nominalizations, in which the perpetrator does not play the role of Agent or is not overtly expressed; c) Constructions that depict the event as a bare happening, such as anticausatives, and actives with nominalizations as first participants.

Overall, Table 7 shows that, in the GBV corpus, conscious or routinized constructional options favor a conceptualization of the GBV event in which the degree of responsibility assigned to perpetrators-agents is relatively low.

\section{Perception experiment - Test 1}

The outcome of the corpus study was empirically tested with two experiments, with the aim of assessing whether and to what degree individuals perceived the responsibility of both perpetrator and victim of GBV according to the syntactic and semantic features of the constructions denoting the deed. The hypothesis tested with these experimental tests was whether different constructions representing GBV triggered different identifications of responsibility for the deed.

The purpose of the first experimental test was two-fold. First, it aimed to replicate for Italian a combination of corpusassisted and perception studies that allows observation of the reaction of readers to the reporting of GBV events in media discourse that had already been adopted for other languages (cf. Henley et al., 1995; Hart, 2018). Second, it aimed to assess whether the same methodology used in previous studies could be replicated for Italian or whether other morpho-syntactic variables ought also to be considered. The first experiment was treated as a preliminary and qualitative investigation of the matter: as Flick (2014) states, among the various definitions and purposes for conducting a qualitative linguistic analysis there is also the identification of variable behaviors between groups and the conditions leading to such differences. Our purpose in conducting test 1 was to address the possible variables influencing the identification of a culprit according not only to syntactic structure but also on the target stimuli, and, therefore, to assess the methodology to be used in a further, more structured and quantitatively oriented analysis (see test 2). Therefore, for the first test we did not aim neither to a quantitative analysis nor, as a consequence, to an analysis involving inferential statistics. Descriptive statistics was simply used to summarize the results of the study.

The preliminary observations drawn from test 1 were used to decide which linguistic variables should be included in a second, broader test on the perception of GBV (see Section 5).

\subsection{Methods and data}

The first perception study recruited participants among the researchers' acquaintances, via personal invitation or posts published on social media. These acquaintances were then asked to invite other participants, aiming for a snowball sampling, which might improve the socio-demographic richness of the participant's pool in a qualitative investigation (Noy 2008). The experiment was distributed online through the Google forms, in order to boost the intrinsic motivation of the participants engaging in a test that did not provide any extrinsic reward (Buhrmester et al. 2011).

The experiment was administered to 159 participants ( 113 females, 44 males, 2 non-binary) with an average age of 30 , all native speakers of Italian. Participants were randomly allocated one of five questionnaires, as can be seen in Table 8 . Each questionnaire tested one of five different syntactic variables, namely, actives, passives with agent, agentless passives, agentless nominal constructions, and nominal constructions with agent.

Table 8

Number of participants per questionnaire.

\begin{tabular}{lll}
\hline Questionnaire $\left(\mathrm{n}^{\circ}\right)$ & Syntactic variable & Participants $\left(\mathrm{n}^{\circ}\right)$ \\
\hline 1 & Active construction & 27 \\
2 & Passive with agent & 36 \\
3 & Agentless passive & 33 \\
4 & Agentless nominal construction & 40 \\
5 & Nominal construction with agent & 23 \\
Total & & 159 \\
\hline
\end{tabular}


When starting the perception test, participants were informed about the experimental conditions and the general goal of the experiment, i.e. the study of the perception of violence in the media. The description of the goal was intentionally not too detailed in order to avoid biasing the answers of the participants. Participants were advised they would be allowed to fill in the questionnaire if they were between 18 and 60 years old, and that their participation was anonymous and voluntary. The possible risks (i.e. exposure to violence lexicon) and advantages of taking part in the experiment (i.e. contributing to scientific research) were also explained, and participants were advised that they could leave the questionnaire at any time if they felt uncomfortable. The structure of the experiment and the tasks were broadly outlined: participants were asked to read the texts provided and then to continue to answer three related questions without referring back to the text. This decision was made to reduce the chances of participants overthinking their responses.

The perception test consisted of six brief texts, including two stimuli and four distractors. Both stimuli and distractors were allegedly taken from the media, but actually, they were each author-constructed to include one of the five syntactic variables considered for the study (see Table 9). The stimuli appeared as stimulus 2 and 5, and they "reported" a case of abuse of a woman and a case of a woman's murder respectively, as was done previously in Henley et al. (1995). The stimuli were structured with an unchanging frame comprising two sentences surrounding the target stimulus, as shown in (18). The first sentence of the frame set the scene for the GBV while the last sentence reported the epilogue of the event.

(18) La polizia è intervenuta ieri notte in una piccola frazione di campagna e si è trovata di fronte a una scena già vista: [STIMULUS] L'ultima telefonata alle forze dell'ordine è partita dai vicini di casa che hanno sentito le urla.

'Police intervened last night in a small country suburb and they faced a previously seen scene: [STIMULUS]. The last phone call to the police came from the neighbors who had heard the screams.'

Table 9 presents the five stimuli used in the two scenarios (abuse and murder) according to the aforementioned five syntactic variables. The latter were independently tested in the five different experimental types; each experimental type evaluated both situations (i.e. abuse and murder). The two stimuli differ with respect to the aspect of the verb: indeed, Fausey and Matlock (2011) have shown that a perfective aspect can lead to a more negative attitude towards a person. However, in this preliminary experiment, it was not possible to completely balance the two stimuli according to the grammatical aspect of the verb, due to the morpho-syntactic restrictions of Italian.

Table 9

Syntactic manipulation for the construction of the stimuli.

\begin{tabular}{|c|c|c|}
\hline Syntactic variable & Stimulus 1: Abuse & Stimulus 2: Murder \\
\hline Active & $\begin{array}{l}\text { Un uomo picchiava ripetutamente la moglie a } \\
\text { causa della gelosia. } \\
\text { 'A man repeatedly beat his wife out of jealousy.' }\end{array}$ & $\begin{array}{l}\text { Un uomo ha ammazzato la moglie al culmine di } \\
\text { una lite causata dalla gelosia. } \\
\text { 'A man killed his wife at the peak of an } \\
\text { argument caused by jealousy.' }\end{array}$ \\
\hline Passive with agent & $\begin{array}{l}\text { Una donna veniva ripetutamente picchiata dal } \\
\text { marito a causa della sua gelosia. } \\
\text { 'A woman was repeatedly beaten by her } \\
\text { husband because of his jealousy.' }\end{array}$ & $\begin{array}{l}\text { Una donna è stata ammazzata dal marito al } \\
\text { culmine di una lite causata dalla gelosia. } \\
\text { 'A woman was killed by her husband at the peak } \\
\text { of an argument caused by jealousy.' }\end{array}$ \\
\hline Agentless passive & $\begin{array}{l}\text { Una donna veniva ripetutamente picchiata a } \\
\text { causa della gelosia del marito. } \\
\text { 'A woman was repeatedly beaten because of her } \\
\text { husband's jealousy.' }\end{array}$ & $\begin{array}{l}\text { Una donna è stata ammazzata al culmine di una } \\
\text { lite causata dalla gelosia. } \\
\text { 'A woman was killed at the peak of an argument } \\
\text { caused by jealousy.' }\end{array}$ \\
\hline Agentless nominal construction & $\begin{array}{l}\text { un pestaggio ripetuto verso la moglie a causa della } \\
\text { gelosia. } \\
\text { 'a repeated beating of the wife out of jealousy.' }\end{array}$ & $\begin{array}{l}\text { l'omicidio della moglie al culmine di una lite } \\
\text { causata dalla gelosia. } \\
\text { 'The murder of the wife at the peak of an } \\
\text { argument caused by jealousy.' }\end{array}$ \\
\hline Nominal construction with agent & $\begin{array}{l}\text { un pestaggio ripetuto verso la moglie da parte del } \\
\text { marito a causa della gelosia. } \\
\text { 'a repeated beating of the wife by the husband } \\
\text { out of jealousy.' }\end{array}$ & $\begin{array}{l}\text { l'omicidio della moglie da parte del marito al } \\
\text { culmine di una lite causata dalla gelosia. } \\
\text { 'The murder of the wife by her husband at the } \\
\text { peak of an argument caused by jealousy.' }\end{array}$ \\
\hline
\end{tabular}

After reading the texts, participants answered three questions, according to a protocol adapted for Italian from Hart (2018a,b,c 412):

(Q1) Who should be accused of the violence?

(Q2) How guilty is the person responsible for the action?

(Q3) How guilty is the person who suffers the action?

The first question was answered through a set of five multiple-choice answers, with the option of entering other values in an additional other section. For the target stimuli, the possible choices were: surely the man, the man, nobody, the wife, definitely the wife. The last two questions were answered with a 7-point Likert scale with the following values: extremely guilty (7), very guilty (6), somewhat guilty (5), guilty (4), not very guilty (3), barely guilty (2), not guilty at all (1). 
The distractors were the same for all experimental types and they appeared as stimuli 1, 3, 4, and 6 . Their structure was similar to those of the stimuli 2 and 5 so that they could reasonably be followed by the same questions posited for the stimuli proper. They were all related to criminal activities, but not about events of GBV. Therefore, the set of multiple-choice answers for Q1 varied slightly with respect to the two target stimuli but maintained the same overall structure.

After completing the experiment, participants were asked for personal data including age, gender, sexual orientation, birth province, residence province, level of education, and political orientation. Gender was firstly included in the list of personal data because of its assumed impact on responsibility attribution in a GBV scenario, although we did not consider it in the following analysis: indeed, the data collected was not quantitatively balanced and we preferred to focus more on linguistic rather than social variables.

\subsection{Analysis}

As shown in Table 8, different numbers of subjects responded to each of the five questionnaires: the number of respondents for condition 5 is indeed quite low, since it comprises only 23 participants. However, this was not a crucial issue since this preliminary test was meant as a qualitative investigation for setting the research method and for improving the stimuli, as previously explained.

First, we investigated who was perceived to be the culprit of abuses against a woman in the different questionnaires. The results presented in Table 10 show that the man was almost always indicated as the culprit. In a single instance of agentless nominal construction, jealousy was regarded as the culprit of the abuse. Since jealousy was not listed among the possible answers, it was added by the participant in the other section, as also occurred in other cases.

Table 10

Identification of the culprit of abuses according to syntactic constructions.

\begin{tabular}{|c|c|c|c|c|c|}
\hline & Active & Passive with agent & Agentless passive & Nominal construction with agent & Agentless nominal construction \\
\hline Surely the man & $22(81.5 \%)$ & $30(83.3 \%)$ & $18(52.9 \%)$ & $16(69.6 \%)$ & $26(65 \%)$ \\
\hline The man & $5(18.5 \%)$ & $6(16.7 \%)$ & $14(41.2 \%)$ & $7(30.4 \%)$ & $13(32.5 \%)$ \\
\hline The jealousy & $0(0 \%)$ & $0(0 \%)$ & $0(0 \%)$ & $0(0 \%)$ & $1(2.5 \%)$ \\
\hline
\end{tabular}

As for the stimuli in the cases of murder, Table 11 shows that, although the victim in the texts was clearly a female, in some questionnaires with nominal constructions and in one case with active, the dead woman was still deemed to be the culprit. With nominal constructions, jealousy was also indicated as the culpable agent, and in two instances the man and the woman were both designated culprits. In the comments to these last two answers, the respondents explained that the woman should be considered as guilty as the man because she had probably done something to cause her partner's violent reaction. Finally, one respondent of the questionnaire featuring agentless passive constructions opined that nobody should be blamed for the murder.

Table 11

Identification of the culprit of female murder according to syntactic constructions.

\begin{tabular}{|c|c|c|c|c|c|}
\hline & Active & Passive with agent & Agentless passive & $\begin{array}{l}\text { Nominal construction } \\
\text { with agent }\end{array}$ & $\begin{array}{l}\text { Agentless nominal } \\
\text { construction }\end{array}$ \\
\hline Surely the man & $18(66.7 \%)$ & $26(72.2 \%)$ & $23(67.6 \%)$ & $17(73.9 \%)$ & $24(60 \%)$ \\
\hline The man & $8(29.6 \%)$ & $10(27.8 \%)$ & $10(29.4 \%)$ & $5(21.7 \%)$ & $12(30 \%)$ \\
\hline The jealousy & $0(0 \%)$ & $0(0 \%)$ & $0(0 \%)$ & $0(0 \%)$ & $1(2.5 \%)$ \\
\hline The woman & $0(0 \%)$ & $0(0 \%)$ & $0(0 \%)$ & $0(0 \%)$ & $1(2.5 \%)$ \\
\hline Surely the woman & $1(3.7 \%)$ & $0(0 \%)$ & $0(0 \%)$ & $0(0 \%)$ & $1(2.5 \%)$ \\
\hline Nobody & $0(0 \%)$ & $0(0 \%)$ & $1(3 \%)$ & $0(0 \%)$ & $0(0 \%)$ \\
\hline Both the man and the woman & $0(0 \%)$ & $0(0 \%)$ & $0(0 \%)$ & $1(4.3 \%)$ & $1(2.5 \%)$ \\
\hline
\end{tabular}

We also checked to see if there was any variability associated with respondents' gender, age or other sociolinguistic variables considered, but the dataset was too small to allow reliable analysis of these kinds of comparisons.

\subsection{Summary of the results}

These first results, albeit preliminary, indicated that a possible difference in the attribution of agentivity to the perpetrator was to be found in the different grammatical constructions and not in the semantics of the verb, with an opposition among active, passive, and nominal forms. However, no difference seemed to emerge between the expression of the agent in the passive and in the nominal constructions. Secondly, the unforeseen emergence of jealousy among the possible culprits for 
both abuses and murders convinced us to also consider this agent, which had not been among the multiple-choice answers offered, and to include it in the second stage of research with the same contextual design.

Moreover, another interesting consideration emerged by comparing the results associated with the two stimuli: contrary to the findings of Henley et al. (1995), the abuse and the murder topics triggered similar answers, although in the killing articles a greater variety of answers emerged. This could be due to the grammatical aspect of the verb, as it has been previously shown by Fausey and Matlock (2011), or by a possible priming effect due to the fact that stimulus 2 (Murder) always occurs after stimulus 1 (Abuse) in the order of stimuli. Respondents could have developed a major familiarity with the test and a different attitude towards its answers, thus causing a potential methodological bias in the research design to be fully considered for the follow-up of the research.

Although the number or respondents to the different questionnaires needed to be balanced more carefully in order to properly compare the different construction types, this first test has shown that the methodology was strong and the stimuli carefully built. Basing on these results, we settled a new experiment with the aim of strengthening these preliminary considerations through a more reliable and quantitative study.

\section{Perception experiment - Test 2}

All the observations that emerged in the first stage of the empirical study were integrated in the design of a second perception test, by narrowing the goal solely to cases of female murders. Setting aside the cases of abuse allowed us to avoid a potential priming effect caused by presenting two target stimuli in the same questionnaire. Furthermore, in line with the results of the first perception study, the number of constructions tested was reduced to three, with an opposition just among active, passive, and nominal constructions, the last two with expressed agent. The results of the test were analysed quantitatively with inferential statistics.

\subsection{Methods and data}

Participants in the second experiment were recruited among the first-year students of the course of Language and Communication at the faculty of Communication, Information, Multimediality (CIM) at University of Pavia (Italy) between October and November 2019. The experiment was distributed to 115 participants (80 females, 35 males). They ranged between 18 and 43 years in age, with an average age of 20.44. All participants were native speakers of Italian. Participants were randomly distributed across three experimental types (i.e. 1, 2 and 3), divided into two experimental subtypes (i.e. A and B; see Table 12). The tests were handed out in paper form at the beginning of a class held by one of the investigators. Participants were told in advance that they would be taking a test for research purposes, and they were alerted that they were neither obligated to participate nor would they be offered any reward for their contribution.

Table 12

Number of participants per experiment type.

\begin{tabular}{lll}
\hline Questionnaire $\left(\mathrm{n}^{\circ}\right)$ & Syntactic variable & Participants $\left(\mathrm{n}^{\circ}\right)$ \\
\hline $1(\mathrm{~A}-\mathrm{B})$ & Active & 38 \\
$2(\mathrm{~A}-\mathrm{B})$ & Passive with agent & 38 \\
$3(\mathrm{~A}-\mathrm{B})$ & Nominal construction with agent & 39 \\
Total & & 115 \\
\hline
\end{tabular}

Participants were asked to fill in the test anonymously and to write down only their age and gender as personal data. They were asked to complete the experiment in 10 minutes, reading the text and answering the related questions carefully but without too much pondering. Each experimental type consisted of a 75-word text, followed by five questions. The texts were similar to the ones of the first experiment. The variable stimulus was preceded by a sentence that introduced the GBV event and it was followed by two sentences that further described the deed. The stimulus reported the killing of a woman by her husband out of jealousy. This killing was presented alternatively with an active construction (A man killed a woman out of jealousy), with a passive construction with agent ( $A$ woman was killed by a man out of jealousy), and with a nominal construction with agent (The killing of a woman by a man out of jealousy).

The experiment tested only three syntactic variables, namely (1) actives, (2) passives, (3) nominal constructions (see also Appendix). Each syntactic variable was investigated by ordering the answers to the related questions in two different ways (i.e. the experimental subtypes A and B), thus reaching a total of $3 \mathrm{X} 2$ sets, since the position of the answers might influence the salience they acquire for the reader (see, for instance, Kress and Van Leeuwen, 2006).

The first and third questions (Q1 and Q3) asked who or what were, respectively, the perpetrator and the victim of the violence. For each question, the five predetermined answers included the woman,jealousy, the man, nothing/nobody, and other, thus allowing participants to freely indicate the perpetrator of the violence. The second and fourth questions (Q2 and Q4) asked how responsible the perpetrator of the violence or the victim were; much as in the first experiment, the possible 
answers were arrayed on a 7-point Likert scale from Not at all to Definitely. Finally, an open question was added asking for cumulative comments on the texts and/or motivations for the given answers.

\subsection{Analysis}

Prior to the analysis of the results of the second perception study, data previously collected were processed in a matrix with the software IBM SPSS 20 in order to run a chi-square test and Cramer's V coefficient for measuring association. It is generally stated that the larger the sample size the more powerful results are obtained, and some authors have claimed that 32 or even 50 participants per condition are needed to perform a powerful statistical analysis (Van Voorhis and Morgan, 2007). However, from various linguistic disciplines it has also been argued that the effect of sample size must be regarded with respect to both the research question under investigation and the numbers of conditions to be tested (Brysbaert, 2019, among others). Furthermore, although participants listed in Table 12 have undertaken six different questionnaires, as explained in the previous section the testing conditions were only 3 (i.e., active, passive and nominalized constructions). Each condition was divided in two questionnaires only in order to present a different order of the answers and avoid a visual priming effect, since a randomization of the answers can not be obtained on a paper questionnaire.

We first considered each question separately, in order to reduce the variability of the answers for the first and third questions to four main variants: the man, the woman, jealousy, other. The other option included multiple answers: for instance, some respondents marked both the woman and jealousy and other respondents wrote down something pertinent to the text but not included among the multiple-choice answers (e.g. the one who committed the crime). Our initial plan was to investigate this other category further, but our univariate analysis showed that this variant was chosen only in 5 cases for the first question (4.3\%) and in 3 cases for the third question (2.6\%). Furthermore, we noticed that Q3 presented the most unbalanced distribution of answers among our four questions, since in $95.7 \%$ of the cases the woman was indicated as the victim of the crime. Conversely, the perpetrator of the violence was indicated as the man in $73 \%$ of the cases, with jealousy selected as the responsible agent in $21.7 \%$ of the answers.

Then, we proceeded by testing to determine whether the syntactic construction of the different stimuli played a role in identifying the responsible agent for the crime. The correlation between the answers to the first question and the construction was statistically significant, and it proved quite good, since the Cramer's V value shows a moderate association $\left(\chi^{2}(6)=20.769, p=.002\right.$, Cramer's $\left.V=0.3\right)$. It should be noted that no differences emerged regarding the order of presentation of the answers (i.e. between questionnaires $\mathrm{A}$ and $\mathrm{B}$ ).

Data in Table 13 shows that the man was indicated as responsible for the violence in $94.7 \%$ of the cases with actives, but this value decreased to $68.4 \%$ with passives and to $56.4 \%$ with nominal constructions. Conversely, responsibility was attributed particularly to jealousy with nominal constructions (41\%) followed by passives (21.1\%); with actives only one respondent indicated jealousy as responsible for GBV. Finally, the only case of responsibility being attributed to the woman (i.e. the victim) was found with a passive construction.

Table 13

Variation in the identification of the responsible of the violence according to syntactic constructions.

\begin{tabular}{llll}
\hline & Active & Passive & Nominal constructions \\
\hline The man & $36(94.7 \%)$ & $26(68.4 \%)$ & $22(56.4 \%)$ \\
The woman & $0(0 \%)$ & $1(2.6 \%)$ & $0(0 \%)$ \\
The jealousy & $1(2.6 \%)$ & $8(21.1 \%)$ & $16(41 \%)$ \\
Other & $1(2.6 \%)$ & $3(7.9 \%)$ & $1(2.6 \%)$ \\
Total & $38(100 \%)$ & $38(100 \%)$ & $39(100 \%)$ \\
\hline
\end{tabular}

We also checked whether the respondents' gender played a role in the attribution of responsibility in the three different constructions. The results presented in Table 14 are statistically significant for both the male $\left(\chi^{2}(6)=15.529\right.$, $p=.017$, Cramer's $V=0.471)$ and the female $\left(\chi^{2}(6)=7.835, \mathrm{p}=.009\right.$, Cramer's $\mathrm{V}=0.221$ ) subgroups.

Table 14

Variation in the identification of the responsible of the violence according to syntactic constructions, divided by the respondents' gender.

\begin{tabular}{|c|c|c|c|c|c|c|}
\hline & \multicolumn{3}{|l|}{ Male } & \multicolumn{3}{|l|}{ Female } \\
\hline & Active & Passive & Nominal construction & Active & Passive & Nominal construction \\
\hline The man & $10(100 \%)$ & 7 (50\%) & $3(27.3 \%)$ & $26(92.9 \%)$ & $19(79.2 \%)$ & $19(67.9 \%)$ \\
\hline The woman & $0(0 \%)$ & $1(7.1 \%)$ & $0(0 \%)$ & $0(0 \%)$ & $0(0 \%)$ & $0(0 \%)$ \\
\hline The jealousy & $0(0 \%)$ & $5(35.7 \%)$ & $8(72.7 \%)$ & $1(3.6 \%)$ & $3(12.5 \%)$ & $8(28.6 \%)$ \\
\hline Other & $0(0 \%)$ & $1(7.1 \%)$ & $0(0 \%)$ & $1(3.6 \%)$ & $2(8.3 \%)$ & $1(3.6 \%)$ \\
\hline Total & $10(100 \%)$ & $14(100 \%)$ & $11(100 \%)$ & $28(100 \%)$ & $24(100 \%)$ & $28(100 \%)$ \\
\hline
\end{tabular}


In both subgroups, the active construction is associated with the man's responsibility in almost all cases. Conversely, male respondents are more prone to attribute the responsibility to jealousy in case of nominal constructions (72.7\%) and with passives (35.7\%), whereas for female respondents the primarily responsible still remains the man. However, albeit statistically significant, these data derive from only a small sample and should be verified by further enquiry with more subjects balanced by gender.

Finally, we checked whether there was a variation in the degree of responsibility attributed to the culprit (Q2) or the victim (Q4) of the violence according to the syntactic construction used to describe the event. Neither correlation proved statistically significant. However, for future investigations, it should be noted that in all constructions, the culprit was always indicated as very or dramatically responsible (degrees 6 and 7 on the Likert scale), with a slight decrease for the nominal constructions. In contrast, the answers for the fourth questions were more widely distributed across the 7 point scale: for all constructions, the victim was still recognized as partially (12 total cases) or seriously (9 cases) responsible for the violence.

\section{Discussion}

Following the lead of previous works on construction grammar and corpus-assisted discourse studies, as well as of works on the triangulation between corpus-assisted discourse studies and experimental linguistics, this work analyzed GBV as reported by Italian media and perceived by Italian readers. The results of the two studies suggest a common emerging pattern, confirming previous findings in the literature on this topic.

Our analysis of the GBV corpus demonstrated that GBV in Italian local daily newspapers is frequently represented through constructions that promote agent-perpetrator backgrounding/suppression or that depict the events as bare happenings. This is consistent with the findings in previous studies of media representation of GBV for other languages: the role of the perpetrator tends to be diminished through agentless nominal or passive constructions, resulting in a suppression or backgrounding of the real culprit (cf. Tranchese and Zollo, 2013; Bohner, 2001).

Our perception tests confirmed these findings. In both tests, but particularly in test 2, although the majority of participants identified the man as the perpetrator, it was evident that this correct identification decreased when nominal and passive constructions were involved. Furthermore, in these stimuli the perpetrator's culpability was more prone to be attributed to an abstract emotion (i.e. jealousy). This finding suggests that the backgrounding strategy produces a focus-change that alters the perception both of the real GBV perpetrator and of his degree of guilt. These findings for Italian support what has been noted for other languages (e.g. Henley et al., 1995; Hart, 2018). In contrast to previous studies, our first perception study showed that abuses appear to be perceived as more serious than murders. However, since the comparison was only indirect, further studies focusing specifically on abuses will help confirm or reject the findings of this study vis-a-vis the topic of GBV and readers' perception of guilt.

\section{Conclusions and future perspectives}

Through an integrated approach combining corpus analysis and perception studies, this paper offers a first investigation into how grammatical constructions contribute to representing GBV events in Italian news language and to readers' perception of the degree of perpetrators' guilt. The analysis of the corpus of local daily newspapers confirmed that GBV events are frequently represented by constructions that put the perpetrators in the background and reduce the directness of their responsibility through leaving the agent unexpressed or depicting the events as bare happenings. These constructions are connected with different perceived degrees of responsibility: within the limits of our study, it was confirmed that nominal and passive constructions diminish the responsibility of perpetrators and shift it toward a third inanimate entity, that is, jealousy.

Further studies on this topic should include larger numbers of respondents for the perception tests and investigate variation in the attribution of GBV responsibility both according to the syntactic constructions and also according to sociolinguistic variables such as readers' age and education level. From a corpus linguistic perspective, more data from local newspapers should be employed to confirm the analysis, together with data from other genres, including, for example, samples of testimony from trials concerning GBV.

\section{Funding information}

This research was carried out within the crowdfunded project Words Matter (https://sites.google.com/unipv.it/ wordsmatter/).

\section{Declaration of competing interest}

No conflicts of interest. 
Appendix - The questionnaire for Test 2

[The different stimuli in the different textual types are reported in Section 5.2 together with a translation].

\section{Istruzioni}

Leggi attentamente il testo seguente e rispondi alle domande sotto.

Non pensare troppo prima di rispondere alle domande, ma segui il primo istinto.

Il questionario è anonimo.

\section{Testo - 1a}

Ieri notte, a B., la polizia è dovuta intervenire per un tragico episodio di violenza domestica. Un uomo, C.F. di 47 anni, ha ucciso la moglie, M.Z. 45 anni, al culmine di una lite per gelosia. Le forze dell'ordine sono sopraggiunte nell'abitazione dopo essere state allertate dai vicini, che avevano sentito le urla, e non hanno potuto far altro che constatare l'avvenuto decesso della donna. L'uomo è stato arrestato e condotto in caserma.

\section{Domanda 1: Chi o cosa è colpevole della violenza?}

L'uomo

La gelosia

La donna

Altro:

Niente/Nessuno

Domanda 2: Quanto è responsabile il colpevole della violenza?

Per nulla

Quasi per nulla

Poco

Né poco né molto

Abbastanza

Molto

Decisamente

Domanda 3: Chi o cosa è vittima della violenza?

L'uomo

La gelosia

La donna

Altro:

Niente/Nessuno

Domanda 4: Quanto è responsabile la vittima della violenza?

Per nulla

Quasi per nulla

Poco

Né poco né molto

Abbastanza

Molto

Decisamente

Domanda 5: Commento libero (solo se vuoi) 


\section{References}

Abis, S., Orrù, P., 2016. Il femminicidio nella stampa italiana: un'indagine linguistica. Gender/Sexuality/Italy 3, 18-33.

Belluati, M. (Ed.), 2021. Femminicidio. Una lettura tra realtà e rappresentazione. Carocci, Roma.

Bohner, G., 2001. Writing about rape: use of the passive voice and other distancing text features as an expression of perceived responsibility of the victim. Br. J. Soc. Psychol. 40, 515-529.

Brysbaert, M., 2019. How many participants do we have to include in properly powered experiments? A tutorial of power analysis with reference tables. J. Cognit. 2 (1), 16-40. https://doi.org/10.5334/joc.72.

Buhrmester, M.D., Blanton, H., Swann, W.B., 2011. Implicit self-esteem: nature, measurement, and a new way forward. J. Pers. Soc. Psychol. 100 (2), 365-385.

Busso, L., Combei, C.R., Tordini, O., 2021. A corpus-based study on the representation of gender-based violence in Italian media. In: Giusti, G., Iannàccaro, G. (Eds.), Language Gender and Hate Speech. A Multidisciplinary Approach. Edizioni Ca' Foscari, Venezia.

Carmi, E., Yates, S.J., Lockley, E., Pawluczuk, A., 2020. Data citizenship: rethinking data literacy in the age of disinformation, misinformation, and malinformation. Inter. Pol. Rev. 9 (2). https://policyreview.info/articles/analysis/data-citizenship-rethinking-data-literacy-age-disinformationmisinformation-and. (Accessed 2 June 2021).

Cennamo, M., 2012. Aspectual constraints on the (anti)causative alternation in Old Italian. Trans. Philol. Soc. 110 (3), $394-421$.

Cennamo, M., 2015. Valency patterns in Italian. In: Malchukov, A., Comrie, B. (Eds.), Valency Classes in the World's Languages. de Gruyter, Berlin, pp. $417-481$.

Charteris-Black, J., 2004. Corpus Approaches to Critical Metaphor Analysis. Palgrave Macmillan, Basingstoke.

Chilton, P.A., 1996. Security Metaphors: Cold War Discourse from Containment to Common House. Peter Lang, New York.

Clark, H.H., Begun, J.S., 1968. The use of syntax in understanding sentences. Br. J. Psychol. 59, $219-229$.

Coates, L., Wade, A., 2007. Language and violence: analysis of four discursive operations. J. Fam. Violence 22 (7), $511-522$.

Croft, W., 2012. Verbs. Aspect and Causal Structure. OUP, Oxford.

De Cesare, A.-M., 2007. Le funzioni del passivo agentivo. Tra sintassi, semantica e testualità. Vox Romanica 66, 32-59.

Dunmire, P.L., 2007. Projecting the Future through Political Discourse: the Case of the Bush Doctrine. Benjamins, Amsterdam.

Ehrlich, S., 2003. Representing Rape: Language and Sexual Consent. Routledge, London.

Fagoaga, C., 1994. Comunicando violencia contra las mujeres. Estud. sobre mensaje periodístico 1, 67-90.

Fausey, C.M., Matlock, T., 2011. Can grammar win elections? Polit. Psychol. 32 (4), 563-574.

Fillmore, C., 1982. Frame semantics. In: Linguistics Society of Korea. Linguistics in the Morning Calm. Hanshin Publishing Co, Seoul, pp. $111-137$.

Flick, 2014. Mapping the field. In: Flick (Ed.), The SAGE Handbook of Qualitative Data Analysis. SAGE, London, pp. 3-18.

Formato, F., 2017. 'Ci sono troie in giro in Parlamento che farebbero di tutto'. Italian female politicians seen through a sexual lens. Gender Lang. 11 (3), 389-414. https://doi.org/10.1558/genl.24572.

Formato, F., 2019. Gender, Discourse and Ideology in Italian. Palgrave Macmillan, Basingstoke.

Fowler, R., 1991. Language in the News: Discourse and Ideology in the Press. Routledge, London.

Fuoli, M., Hart, C., 2018. Trust-building strategies in corporate discourse: an experimental study. Discourse Soc. 29 (5), $514-552$.

Gabrielatos, C., Baker, P., 2008. Fleeing, sneaking, flooding: a corpus analysis of discursive constructions of refugees and asylum seekers in the UK press 1996-2005. J. Engl. Ling. 36, 5-38.

Goddard, C., Saunders, B.J., 2000. The gender neglect and textual abuse of children in the print media. Child Abuse Rev. 9, $37-48$.

Goldberg, A.E., 1995. Constructions: A Construction Grammar Approach to Argument Structure. University of Chicago Press, Chicago.

Graddoll, D., Swan, J., 1989. Gender Voices. Blackwell, Oxford.

Hart, C., 2010. Critical Discourse Analysis and Cognitive Science: New Perspectives on Immigration Discourse. Palgrave, Basingstoke.

Hart, C., 2011. Moving beyond metaphor in the Cognitive Linguistic approach to CDA: construal operations in immigration discourse. In: Hart, C. (Ed.), Critical Discourse Studies in Context and Cognition. John Benjamins, Amsterdam, pp. 171-192.

Hart, C., 2013. Event-construal in press reports of violence in political protests: a Cognitive Linguistic Approach to CDA. J. Lang. Polit. 12 (3), $400-423$.

Hart, C., 2015. Viewpoint in linguistic discourse: space and evaluation in news reports of political protests. Crit. Discourse Stud. $12,238-260$.

Hart, C., 2018a. Event-frames affect blame assignment and perception of aggression in discourse on political protests: an experimental case study in critical discourse analysis. Appl. Linguist. 39 (3), 400-421.

Hart, C., 2018b. 'Riots engulfed the city': an experimental study investigating the legitimating effects of fire metaphors in discourses of disorder. Discourse Soc. 29 (3), 279-298.

Hart, C., 2018c. Trust-building strategies in corporate discourse: an experimental study. Discourse Soc. 29 (5), 514-552.

Hart, C., 2021. Animals vs. armies: resistance to extreme metaphors in anti-immigration discourse. J. Lang. Polit. 20 (2), $226-253$.

Hart, C., Fuoli, M., 2020. Objectification strategies outperform subjectification strategies in military interventionist discourses. J. Pragmat. 162 , 17-28.

Haspelmath, M., Calude, A., Spagnol, M., Narrog, H., Bamyacı, E., 2014. Coding causal-noncausal verb alternations: a form-frequency correspondence explanation. J. Linguist. 50 (3), 587-625.

Henley, N.M., Miller, M., Beazley, J., 1995. Syntax, semantics, and sexual violence: agency and the passive voice. J. Lang. Soc. Psychol. $14,60-84$.

Hopper, P.J., Thompson, S.A., 1980. Transitivity in grammar and discourse. Language 56 (2), 251-299.

Jezek, E., 2004. Types et degrés de verbes supports en italien. In: Gross, G., De Pontonx, S. (Eds.), Les verbes supports: nouvel état des lieux. Special issue of Linguisticae Investigationes, vol. 27, pp. 269-285 (2).

Johnson, M.P., 1995. Patriarchal terrorism and common couple violence: two forms of violence against women. J. Marriage Fam. 57, $283-294$.

Johnson-Laird, P.N., 1977. The passive paradox: a reply to Costermans and Hupet. Br. J. Psychol. 68, 113-116.

Karadole, C., 2012. Anti-violence centres and shelters in Italy: history and meaning of women's struggles against male violence. Interdiscip. J. Fam. Stud. 17 (2), 238-242.

Kemmer, S., 1993. The Middle Voice. Benjamins, Amsterdam.

Kress, G., Van Leeuwen, T., 2006. Reading Images: A Grammar of Visual Design. Routledge, London/New York.

Lakoff, R., 1973. Language and woman's place. Lang. Soc. 2 (1), 45-79.

Lakoff, R., 1975. Language and Woman's Place. Harper, New York.

Lakoff, G., 2004. Don't Think of an Elephant! the All New: Know Your Values and Frame the Debate. Chelsea Green Publishing, White River Junction.

Lakoff, G., 2009. The Political Mind. Penguin, London.

Lakoff, G., Johnson, M., 1980. Metaphors We Live by. University of Chicago Press, Chicago.

Langacker, R.W., 1991. Foundations of Cognitive Grammar, vol. II. Descriptive application, Stanford: Stanford University Press.

Langacker, R.W., 2006. Dimensions of defocusing. In: Tsunoda, T., Kageyama, T. (Eds.), Voice and Grammatical Relations. Benjamins, Amsterdam, pp. $115-138$.

Luraghi, S., Narrog, H. (Eds.), 2014. Perspectives on Semantic Roles. Benjamins, Amsterdam.

Mills, S., 2008. Language and Sexism. CUP, Cambridge.

Monckton-Smith, J., 2012. Murder, Gender and the Media: Narratives of Gendered Love. Palgrave, Basingstoke.

Noy, C., 2008. Sampling knowledge: the hermeneutics of snowball sampling in qualitative research. Int. J. Soc. Res. Methodol. 11 (4), $327-344$.

O'Donnell, 2008. The UAM CorpusTool: Software for corpus annotation and exploration. In: Callejas, Carmen, et al. (Eds.), Applied Linguistics Now: Understanding Language and Mind / La Lingüística Aplicada Hoy: Comprendiendo el Lenguaje y la Mente. Universidad de Almería, Almería, pp. $1433-1447$.

O'Donnell, M. 2012. UAM Corpus Tool. Version 2.8 User Manual. (Accessed 19 August 2021)

O'Halloran, K., 2007. Critical discourse analysis and the corpus-informed interpretation of metaphor at the register level. Appl. Linguist. $28,1-24$. 
O'Hara, S., 2012. Monsters, playboys, virgins and whores: rape myths in the news media's coverage of sexual violence. Lang. Lit. 21 (3), $247-259$.

Pinelli, E., Zanchi, C., 2021. Gender-based violence in Italian local newspapers: how argument structure constructions can diminish Perpetrator's responsibility. In: Fragonara, A., Anesa, P. (Eds.), Discourse Processes between Reason and Emotion. Palgrave Macmillan, Basingstoke, pp. 117-143.

Rueschemeyer, S.-A., Gaskell, G.M., 2018. The Oxford Handbook of Psycholinguistics. OUP, Oxford.

Sabatini, A., 1986. Raccomandazioni Per Un Uso Non Sessista Della Lingua Italiana. Presidenza del Consiglio dei Ministri, Dipartimento per l’Informazione e l'Editoria.

Sabatini, A., 1993. Il sessismo nella lingua italiana. In: collaborazione con M. Mariani, E. Billi \& A. Santangelo. Presidenza del Consiglio dei Ministri, Dipartimento per l'Informazione e l'Editoria.

Sansò, A., 2006. 'Agent defocusing’ revisited. Passive and impersonal constructions in some European languages. In: Abraham, W., Leisiö, L. (Eds.), Passivization and Typology. Form and Function. Benjamins, Amsterdam, pp. 232-273.

Sansò, A., 2016. Agent-defocusing constructions from nominalized VPs. A cross-linguistic type? Stud. Lang. 40 (4), 894-954.

Santa Ana, O., 2002. Brown Tide Rising: Metaphors of Latinos in Contemporary American Public Discourse. University of Texas Press, Austin.

Santaemilia, J., Maruenda, S., 2014. The linguistic representation of gender violence in written media discourse: the term 'woman' in Spanish contemporary newspapers. J. Lang. Aggress. Confl. 2 (2), 249-273.

Somma, A.L., Maestri, G., 2020. Il Sessismo Nella Lingua Italiana. Trent'anni dopo Alma Sabatini, Roma: Blonk.

Subtirelu, N.C., Gopavaram, S.R., 2016. Crowdsourcing critical discourse analysis: using Amazon's Mechanical Turk to explore readers' uptake of comments about Language on RateMyProfessors.com. CADAAD 8 (1), 38-57.

Tannenbaum, P.H., Williams, F., 1968. Generation of active and passive sentences as a function of subject or object focus. J. Verb. Learn. Verb. Behav. 7, 246-250.

Tranchese, A., Zollo, S.A., 2013. The construction of gender-based violence in the British printed and broadcast media. Crit. Approaches Discourse Anal. Across Discipl. 7 (1), 141-163.

Turner, E.A., Rommetveit, R., 1968. Focus of attention in recall of active and passive sentences. J. Verb. Learn. Verb. Behav. 7, 543-548.

Valvason, E., 2021. The semantics of sustainable development: A corpus-assisted, ecological analysis of discourse across languages. PhD dissertation. University of Pavia.

van Dijk, T.A., 2008a. Critical discourse analysis and nominalization: problem or pseudo problem? Discourse Soc. 19 (6), $821-828$.

van Dijk, T.A., 2008b. Discourse and Power. Palgrave Macmillan, New York.

Van Voorhis, C.R.W., Morgan, B.L., 2007. Understanding power and rules of thumb for determining sample size. Tutor. Quant. Meth. Psychol. 3 (2), 43-50.

Wykes, M., 1995. Passion, marriage and murder. In: Dobash, R.P., Noaks, L., Dobash, R.E. (Eds.), Gender and Crime. University of Wales Press, Cardiff, pp. 49-76.

Chiara Meluzzi is a Research Fellow in Linguistics at University of Milan "La Statale". She has previously worked at Scuola Normale Superiore in Pisa and at University of Pavia. Her main research interests include pragmatics, language variation and sociophonetics.

Erica Pinelli is a Research Fellow in Slavic Studies at University of Pavia, where she teaches Russian Language. Her main research interests are Russian Linguistics, Cognitive Linguistics, political and media discourse.

Elena Valvason holds a PhD in Linguistics from Universities of Pavia and Bergamo. She works on the discursive construction of sustainable development in political and media discourse with a corpus-assisted approach.

Chiara Zanchi is a Postdoc Fellow at University of Pavia, where she teaches Language Data Analysis (MA in Linguistics). She is mainly interested in the syntax and pragmatics of ancient and modern IE languages. 